\title{
CONGENITAL INTESTINAL OBSTRUCTION, WITH THE REPORT OF A CASE *
}

\author{
A. V. ST. GEORGE, M.D. \\ NEW YORK
}

\begin{abstract}
Although the standard works on embryology, anatomy, pathology and pediatrics seldom refer to the interesting condition of congenital obstruction of the small intestine, isolated case reports are not infrequent. In the large necropsy service of Bellevue Hospital during the past fourteen years, congenital obstruction of the intestine was encountered twice only.
\end{abstract}

Louise Cordes ${ }^{1}$ collected fifty-six cases from the literature up to 1901 , and reported a case of her own. Ballantyne, ${ }^{2}$ in discussing the condition, says: "Antenatal narrowing or occlusion of the intestine is not very rare, but being an internal malformation, doubtless often escapes discovery." He reported a case with which he was acquainted and mentions the cases published by Durante ${ }^{3}$ (two cases), Jackson, ${ }^{4}$ A. Katz, ${ }^{5}$ and Kirmisson, ${ }^{6}$ not included by Cordes. Kirmisson's patient had been operated on for anal atresia soon after birth "with apparent success;" however, the infant died and necropsy showed a valvular obstruction of the duodenum, in addition to the anal defect. Spriggs ${ }^{7}$ gives an interesting account of twenty-four cases, with an excellent discussion and extensive references to the literature. Other cases of this condition as well as cases of congenital obstruction of the jejunum and cases of multiple obstructions have been reported. In an extensive search of the literature I have found a total of 143 cases of all kinds of congenital obstructions of the small intestine. The reader is referred to the appended list of references for details of these cases.

Kaufmann ${ }^{8}$ asserts that atresia of the small intestine is especially common at the point where the common duct joins the duct of Wirsung at its entry into the duodenum. Combinations of duodenal atresia with

* Submitted for publication March 12, 1918.

* From the Pathological Department of Bellevue and Allied Hospitals, Dr. Douglas Symmers, Acting Director.

1. Cordes, L.: Arch. Pediat., 1901, 18, 401.

2. Ballantyne, J. W.: Manual of Antenatal Pathology and Hygiene, 1905; Tr. Edinburgh Obst. Soc., 1892, 17, 133.

3. Durante: Bull. Soc. anat. de Paris, 1901, 76, 593.

4. Jackson, J. B. S.: Boston Med. and Surg. Jour., 1858, 59, 355.

5. Katz, A.: Bull. Soc. anat. de Paris, 1901, 76, 471.

6. Kirmisson, E.: Traité des maladies chirurgicales, 1898, p. 412.

7. Spriggs, N. I.: Guy's Hosp. Rep., 1912.

8. Kaufmann, Eduard: Spezielle pathologische Anatomie, 1, 460, 6th ed. 
defective development of the esophagus and with atresia of the rectum have been observed. Drennan and Clark ${ }^{9}$ state that but one point of actual closure usually exists, but that, in addition, one or more points of stenosis may be found.

Productive fetal peritonitis and enteritis, thrombosis of the mesenteric vessels, anomalies in the development and distribution of the blood vessels, volvulus, intussusception and anomalies of the yolk stalk have been given as the possible causes. Rowland ${ }^{10}$ reported one case and mentioned four others which, at operation, showed a complete twist of the mesentery of the small intestine. He also says that inspissated meconium may cause complete obstruction, and that this may be fatal or may be spontaneously relieved. He refers to a fatal case. Holt $^{11}$ believes that congenital syphilis may be an etiologic factor. As Cordes says: "The aforementioned causes certainly do not explain the greater number of the cases and other factors, probably developmental defects, coexist."

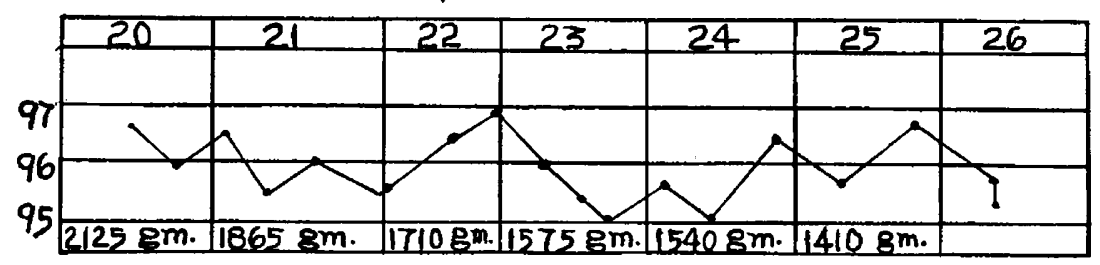

Fig. 1.-Temperature curve and weight variations.

Kreuter (quoted by Kaufmann ${ }^{8}$ ) asserts that there is absence or imperfect development of the lumen of the intestinal canal at a certain time in the development of the embryo (thirty to sixty days). At first the intestine is hollow, but as a result of hyperplasia of the lining epithelium, temporary closure results, which, in the normal fetus, later reopens. Failure to reopen gives various types of atresia or stenosis. Schridde denies this, having never found epithelial atresias. Forssner, ${ }^{12}$ however, supports Kreuter's hypothesis, stating that just above the narrow point, as a result of swallowing amniotic fluid, there is enormous dilatation of that portion of the intestine with an accompanying hypertrophy of the muscularis. Purulent infiltration of the intestine and perforation may result. The lower segment collapses, the wall atrophies and the lumen may be totally obliterated.

9. Drennan and Clark: Am. Jour. Dis. Child., 1915, 10, 360.

10. Rowland, V. C.: Am. Jour. Dis. Child., 1915, 9, 455.

11. Holt, L. E.: Diseases of Infancy and Childhood, 1916.

12. Forssner, H.: Hygiea, Stockholm, 1912, 74, 1168; Ibid., Arch. f. klin. Chir., Berl., 1912, p. 477 ; Ibid., Zentralbl. f. Chir., Leipzig, 1913, 40, 193. 
Thorel's ${ }^{13}$ case had seven points of atresia. He described the epithelial proliferation as the cause in his case and believed that it is the probable cause in most cases, unless there is rotation of the intestine, which, however, is very rare.

Quain ${ }^{14}$ and Bailey and Miller ${ }^{15}$ agree with Kreuter's theory as to the mode of origin of this condition, and considering the embryologic

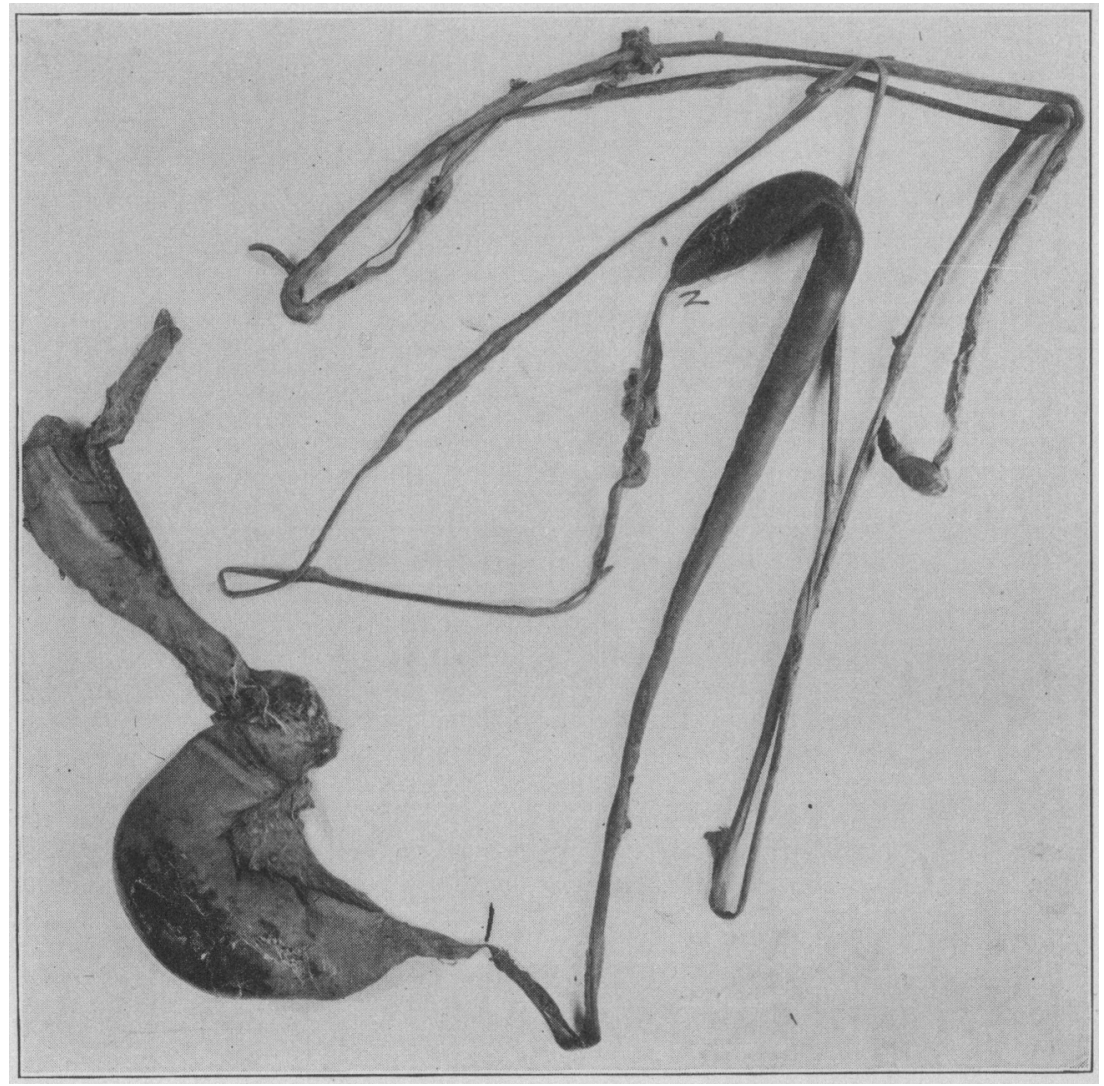

Fig. 2.-Large and small intestine showing strictures at 1 and 2

development of the intestine, it is evident that this process will account for a considerable number, if not the majority, of the cases of congenital intestinal obstruction.

The following symptoms, which were not recorded in our case, are of sufficient importance to remember in arriving at a diagnosis.

13. Thorel, F.: München. med. Wchnschr., 1899, 46, 1202.

14. Quain: System of Anatomy, Embryology, 1, Part 1, Ed. 10, 1896, p. 99.

15. Bailey and Miller: Textbook of Embryology, Ed. 1, 1910, p. 358. 
Schwalbe ${ }^{16}$ noted that in high stenosis the abdomen is retracted and in low stenosis the abdomen protrudes.

Pfaundler and Schlossmann ${ }^{17}$ mention the following symptoms: Abdominal pain, obstinate constipation, deficient flatus, uncontrollable vomiting (at first food, later mucus, bile, blood and "kot"), meteorism, purposeless visible peristalsis, intestinal spasticity, tumor (Nothnagel's phenomenon) and finally collapse. They divide them into obstructions occurring in the small intestine and those in the colon and make a differential diagnosis according to the following table:

\begin{tabular}{|c|c|c|}
\hline & Obstruction in Small Intestine & Obstruction in Colon (Lower Half) \\
\hline $\begin{array}{l}\text { Meteorism....... } \\
\text { Vomiting........ } \\
\text { Urine........... } \\
\text { Collapse........ }\end{array}$ & $\begin{array}{l}\text { Changeable, moderate and only epi- } \\
\text { gastric lower and side parts of } \\
\text { abdomen sunken. } \\
\text { None, or occasionally fecal } \\
\text { Indicanuria, oliguria } \\
\text { Very severe }\end{array}$ & $\begin{array}{c}\text { Constant, strong and universal; } \\
\text { "Kotwülste" palpable } \\
\text { Fecal } \\
\text { No indicanuria; no oliguria } \\
\text { Moderate }\end{array}$ \\
\hline
\end{tabular}

\section{REPORT OF CASE}

The following case came to necropsy in Bellevue Hospital, Sept. 26, 1917.

History.-A girl, the second of twins, was born Sept. 20, 1917, of a healthy mother (Di R. M-3, service of Dr. J. C. Edgar, visiting obstetrician to Bellevue Hospital, to whom I am indebted for permission to abstract the clinical record). Family history negative; Wassermann on mother negative. At birth the patient was bleeding quite profusely from the nose and mouth. No other abnormality was noted. Shortly after birth the infant passed a small amount of meconium. The bleeding continued, although to a less extent, through the day, and at 8:30 p. m., 10 c.c. of horse serum were given intramuscularly. Thereafter bleeding diminished very materially. The total amount of blood lost during this time was estimated at about $1 \frac{1 / 2}{2}$ ounces.

September 21. Immediately after the administration of a small amount of water the infant vomited a brownish fluid. When given the breast at $3 \mathrm{p}$. m., the child nursed exceedingly well, but a few minutes later vomited a thick brown residue. Blood oozed from nose and mouth throughout the day. At $5 \mathrm{p}$. m. 10 c.c. of the mother's blood was given, with but slight improvement in the child's bleeding. There was no bowel movement and the urine was scanty.

September 22. One ounce of saline was given into the rectum but was not retained; large amounts of mucus were expelled. Oozing of blood from mouth and nose occurred during the entire day, but stopped during the night. The child continued to vomit dark brown material after each feeding. There was no bowel movement.

September 23. Vomiting continued after each feeding. Vomitus this day was thick yellowish streaked with brown. Three ounces of olive oil given per rectum was not retained but was immediately expelled together with mucus. Bleeding continued. Pulse rapid (120), weak.

16. Schwalbe, E.: Morphologie der Missbildungen des Menschen und der Tiere. Ed. 1, 1909, 3, 58.

17. Pfaundler and Schlossmann: Handb. der Kinderh., 1, Part 1, Ed. 1, 1906, p. 72. 
September 24. Eight drops of castor oil and saline enema given but without effect. Other symptoms as heretofore. Wrapped in cotton; kept warm.

September 25. Symptoms as before; bleeding continued; urine continued scanty.

September 26. Died at 1:55 p. m., following a profuse vomiting of yellowish material containing a large amount of blood.

Clinical Diagnosis.-Intestinal obstruction (congenital); hemorrhagic disease of the new-born.

Necropsy.-The body was that of an emaciated, white female infant, weighing $1,325 \mathrm{gm}$. and measuring $42 \mathrm{~cm}$. in length. Rigor mortis was absent, and there

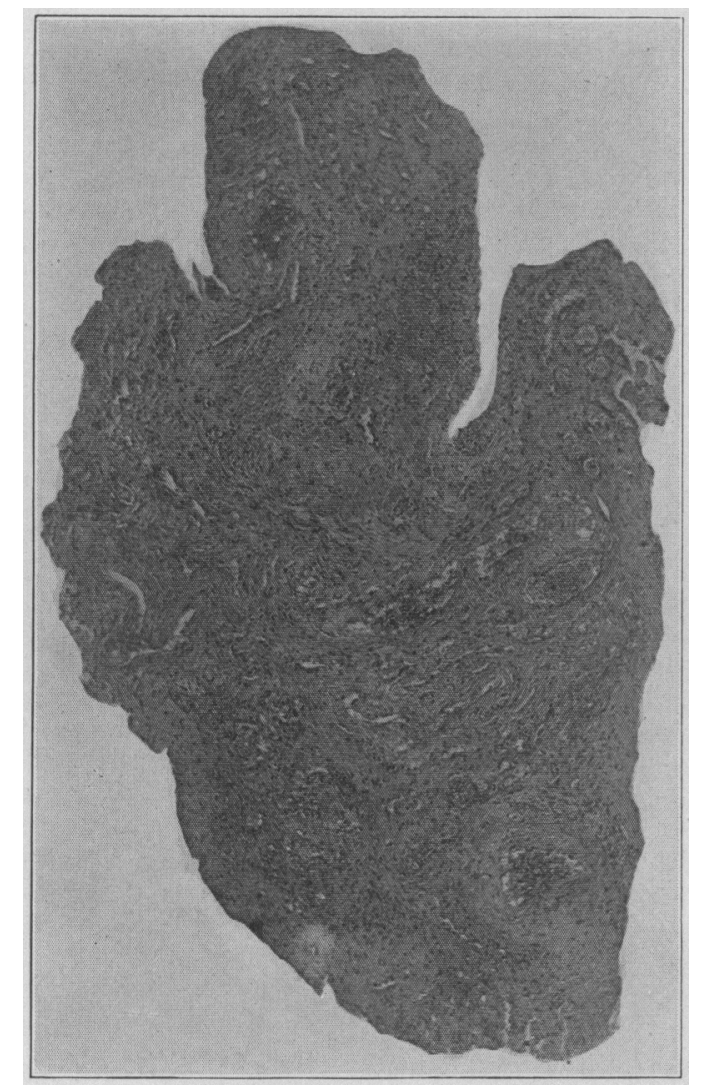

Fig. 3.-Microscopic section taken at 1 in Figure 2.

was a slight postmortem diffusion over the back. The entire skin was markedly icteric and there were ecchymotic areas over the lower extremities, on the back and the chest. The scalp was clean and covered by a fair amount of fine, long, black hair. Both fontanels were open and depressed. The pupils were equal and in middilatation; the sclerae were markedly icteric; conjunctivae free of petechiae and discharge. The nose and ears externally were negative. The lips were pale; the mucous membrane of the mouth was smooth. The tongue was dry, not fissured and there were no ulcerations present. The superficial lymph nodes were palpable only in the groin. The chest was symmetrical. The outlet of the thorax was acute. The abdomen was scaphoid. The external genitalia were normal. The extremities were normal. 
The abdomen was free of fluid. The umbilical vein and both hypogastric arteries were patent. The greater portion of the large and small intestines was collapsed. There were numerous subperitoneal hemorrhages in the parietal and visceral peritoneum covering the intestines, the stomach and the liver. The mesenteric and retroperitoneal lymph nodes were not enlarged. The liver extended about $15 \mathrm{~mm}$. below the costal margin. The diaphragm reached the fourth space on both sides. The stomach and about $9 \mathrm{~cm}$. of the duodenum were distended with a dark semi-fluid material; and there was an apparently complete stricture of the duodenum, following which the jejunum, for a distance of about $20 \mathrm{~cm}$., contained similar semi-fluid residue, and at this point there was another apparently complete stricture (Fig. 2). It was impossible to force the

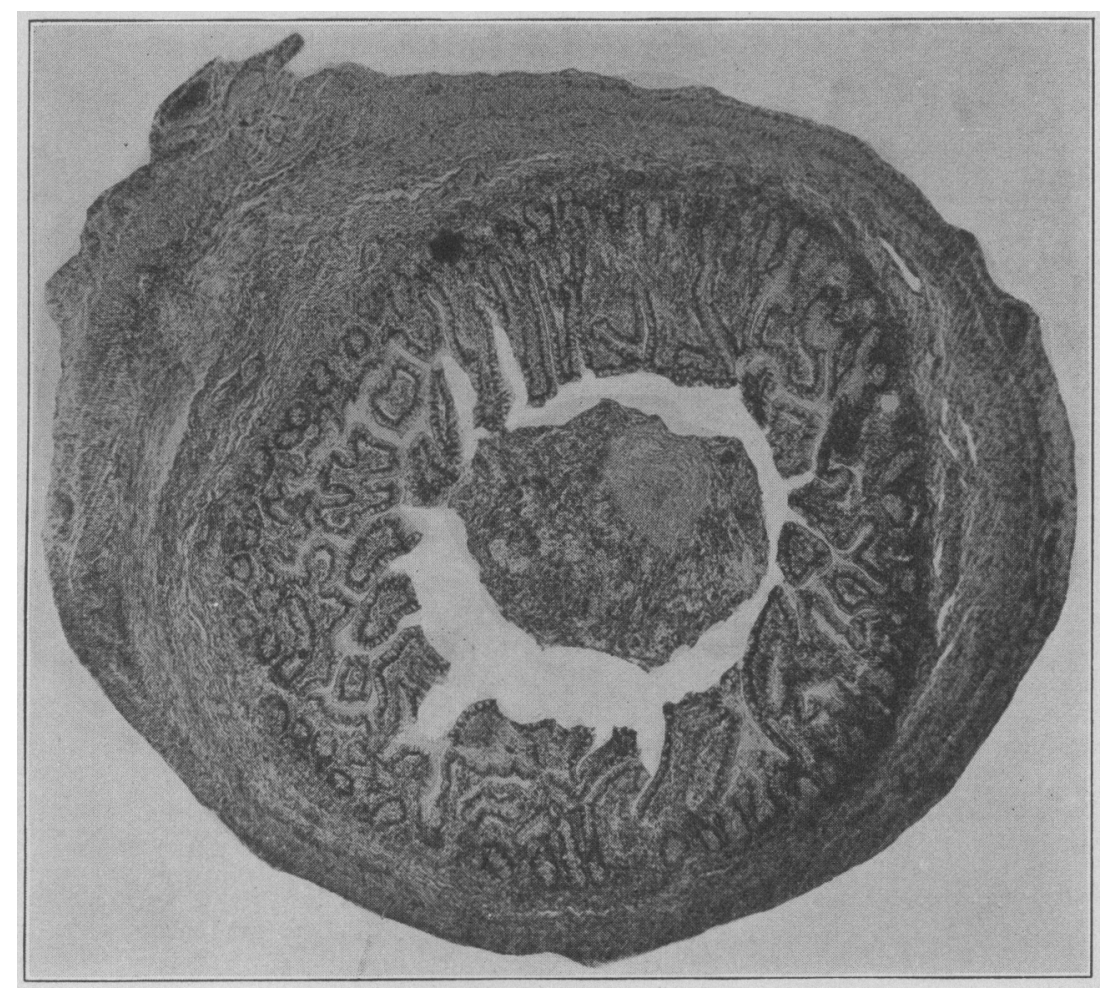

Fig. 4.--Microscopic section taken at 2 in Figure 2

intestinal contents through the stricture. The organs were in their proper position. There was no rotation of any portion of the intestine. The remainder of both the small and large intestines was totally collapsed. The appendix was small and lay free over the pelvic brim. A probe could be inserted into the rectum for a distance of $1 \frac{1 / 4}{4}$ inches.

The right pleural cavity contained about 0.5 c.c. of a dark, hemorrhagic fluid. There were no adhesions. Over both the visceral and parietal pleurae of both lungs there were a number of large hemorrhages scattered in irregular fashion and presenting no definite demarcation. The pleural surfaces were smooth and of a bright red color, except where the irregular darkened hemorrhagic areas were found. The lung on section cut smoothly, presenting an irregularly reddish, mottled, crepitant surface, from which but little fluid could be expressed. The 
bronchi were normal and were free of fluid. The peribronchial and mediastinal lymph nodes were not enlarged. The branches of the pulmonary artery were normal.

Heart: The precordial area was normal. The pericardial sac contained a small amount of dark hemorrhagic fluid and there were also some hemorrhagic areas on the epicardium. There were no petechiae present. The heart was of normal size, dark red in color. The epicardium was smooth. There were no subendocardial hemorrhages present. The heart chambers contained a moderate amount of dark red fluid blood. The valves were normal and apparently competent. The fossa ovalis was small, the foramen was patent. The myocardium was smooth and, on section, of a dark red color. The coronary vessels, as far as examined, were normal. The aorta and pulmonary artery were both smooth and elastic and without intimal change. The ductus arteriosus was closed.

The thymus was of normal size and weighed about $10 \mathrm{gm}$. On section it presented pale pink, glandular tissue.

Liver: This was of normal size. The capsule was not thickened. It was of a dark red color. On section it presented a firm, dark red surface from which a good deal of blood exuded. The vessels and duct were patent. The latter was considerably distended with bile. The gallbladder wall was smooth. The organ contained a small amount of thick, yellowish green bile.

Spleen: This organ was of normal size; it was firm. The capsule was not thickened. On section it presented a dark red surface in which the malpighian corpuscles were not prominent.

Pancreas: This was small, of normal consistency and the section was normal.

Kidneys: The kidneys were small and embedded in but little fat. They were considerably lobulated. The capsule stripped readily, leaving a pale reddish surface. On section there was distinct demarcation between cortex and medulla. The pyramids appeared a little swollen and contained well defined, radiating, orange-colored uric acid infarcts. The pelvis of the right kidney contained a few small, hemorrhagic areas. The ureters were normal.

The bladder was contracted and contained a small amount of urine. The wall was smooth and without lesion in the gross.

The adrenals were of normal size and on section, normal. There were no hemorrhages seen.

The uterus, tubes and ovaries were normal in the gross.

Organs of the neck and throat: The tonsils were small and pale pink in color. The trachea was normal in appearance. The esophagus to within about $1 \frac{1}{2} \mathrm{~cm}$. of the cardia was normal. The remainder of the gastro-intestinal tract was not opened, but preserved in formaldehyd solution for subsequent sectioning. The thyroid was small; on section normal.

Head: The scalp was readily stripped from the calvarium. The anterior and posterior fontanels were both patent and depressed. The sutures overrode to a considerable degree. The calvarium was readily removed. The dura mater was normal. There was a considerable amount of pial edema present. The brain was soft. Section of the cerebral hemispheres was normal. The lateral ventricles were without fluid. There were no hemorrhages anywhere. The floor of the fourth ventricle had a decided yellowish tinge; otherwise it appeared normal. The examination of the middle ears and the sinuses accessory to the nose was negative.

Examination of the lower extremity of the right femur was negative.

Anatomic Diagnosis.-Congenital intestinal obstruction; hemorrhagic disease of the new-born (involving skin and serous surfaces); icterus neonatorum (obstructive jaundice?) ; uric acid infarction of kidney; pial edema, marked; patent umbilical vein, hypogastric arteries and foramen ovale.

Microscopic examination of the tissues and organs showed nothing remarkable.

Microscopic sections taken from the intestine at points indicated in the photographs (Figs. 3 and 4 ) show complete destruction of the lumen of the duodenum (1) and replacement by fibrous tissue in which there are a number of 
blood vessels. There is no suggestion of a lumen. Section (2) made through the second point of constriction shows a lumen which is markedly diminished in caliber and occupied by a small blood clot.

The anatomic details of the foregoing case are in close agreement with those of three cases recorded by Ducros, ${ }^{16}$ who found complete atresia of the duodenum-jejunum junction due to the presence of a fibrous mass replacing the lumen.

Bibliography of additional cases not referred to by numbers:

Pied: Jour. de méd., chir., pharm., 1802, 3, 227.

Gaertner: Jahrb. f. Kinderh., New Series, 1883, 20, 403.

MacDonald, A.: Tr. Edinburgh Obst. Soc., 1885, 10, 229.

Thomson, J.: Tr. Edinburgh Obst. Soc., 1892, 17, 182.

Kirchner: Berl. klin. Wchnschr., 1886, 23, 444.

Turner, F. C.: Tr. Path. Soc. Lond., 1886, 38, 145.

Hess, C.: Deutsch. med. Wchnschr., 1897, 23, 218.

Heymann, F.: Monatschr. f. Geburtsh. u. Gynäk., 1899, 10, 186.

Wyss, M. O.: Beitr. z. klin. Chir., 1900, 26, 631.

Kermauner, F.: Virchow's Arch. f. path. Anat., 1912, 95, 932

Klippel and Teil: Bull. et mém. Soc. anat. de Paris, 1912, 87, 144.

Klippel and Teil: Gaz. méd. du centre, Tours, 1912, 17, 100.

Lafoncarde: Bull. et mém. Soc. de chir. de Paris, New Series, 1912, 38, 811.

Peraire, M.: Paris chir., 1912, 4, 463.

Wilcox, G. A.: Jour. Med. Assn. Georgia, 1912, 1, 145.

Zarfl: Mitt. d. gesellsch. f. inn. Med. u. Kinderh., Vienna, 1912, 11, 130.

Zarfl: Wien. med. Wchnschr., 1912, 62, 163.

Henneguier, A.: Bull. Soc. de Chir., Paris, 1912, No. 442, p. 83.

Nurberger, L.: Samml. klin. Vortr., Leipzig, New Series, 1913, No. 679.

Trumpp: Jahrb. f. Kinderh., New Series, 1912, 76, 678.

Weber: München. med. Wchnschr., 1913, 60, 212.

Weber: Jahrb. d. Gesellsch. f. Nat. u. Heilk., Dresd., 1912, 13, 39.

Cowell, E. M.: Quart. Jour. Med., 1911, 5, 401.

Hertz, A. F.: Proc. Roy. Soc. Med., 1911, 5, Sect. Stud. Dis. Child., p. 169.

Hoffmann, K.: Gynäk. Rundschau, Berl. u. Wien., 1912, 6, 173.

Baugher, A. H.: Tr. Chicago Path. Soc., 1913, 9, 34.

Benn: Arb. a. d. path. Anat. Inst. z. Tübingen, Leipzig, 1914, 9, 129.

Zimpton: Boston Med. and Surg. Jour., 1914, 170, 916.

Lyons: Tr. Am. Assn. Obst. and Gynec., 1914, 26, 435.

Melchior: Berl. klin. Wchnschr., 1914, 51, 1161.

Petrivalsky: Casop. lek cesk. v. Prazl., 1913, 52, 871.

Veszpremi, D.: Beitr. z. path. Anat. u. z. allg. Path., Jena, 1914, 60, 124.

Bazin, A. T.: Canadian Med. Assn. Jour., 1915, 5, 697.

Ernst, N. P.: Helbred. Hosp. Tid., Copenhagen, 1915, S. R., 8, 1103.

Wolf: Lwow. tygodn. Lek., 1913, 8, 236.

Bogert, F. N.: Arch. Pediat., 1916, 33, 248; 1918, 35, 45.

Lardennois: Bult. Soc. anat. de Paris, 1898, p. 805.

18. Ducros: Quoted by Allbutt: System of Mediciine, 3, p. 330, Ed. 2. 